\title{
The Important Roles of Interstitial Cells of Cajal and Cholinergic Receptors on Diabetes Related Dysfunction of Colon
}

\author{
Jae Yeoul Jun
}

Department of Physiology, College of Medicine, Chosun University, Gwangju, Korea

\author{
Article: Alterations of colonic contractility in long-term diabetic rat model \\ Kim SJ, Park JH, Song DK, et al \\ (J Neurogastroenterol Motil 2011;17:372-380)
}

Diabetes mellitus (DM) is a chronic disease that develops at the time of inappropriate insulin production and utilization. Lifelong medical attention is required for inhibiting the development of potentially devastating late complications of DM.

Diabetic patients are generally affected with gastrointestinal (GI) disorders. ${ }^{1,2}$ The common symptoms are dysphagia, satiety, reflux, constipation, abdominal pain, nausea, vomiting and diarrhea. ${ }^{3-5}$ These symptoms are eventually caused by the neuropathy involving the entire GI tract. In particular, it has been well known that abnormal motility of the GI tract occurs in the development of diabetes. ${ }^{6}$ So far many studies have demonstrated that DM patients have slow transit and abnormal motility. GI abnormalities such as motor dysfunction, autonomic neuropathy, inadequate glucose control, psychological factors, or morphological changing in the GI tract have been reported. ${ }^{7-9}$ However, the underlying mechanism is not clearly understood.

Interstitial cells of Cajal (ICCs) are known as pacemaking cells, mediators of neurotransmission in GI tract and play a crucial roles in GI motility. ${ }^{10-12}$ They are network-forming cells con- nected electrically with each other and with smooth muscle cells via gap junctions. ${ }^{13}$ Recently, it has been shown that some populations of ICCs express the proto-oncogene c-Kit, and the antibodies to its gene product, the Kit (or c-Kit) receptor which a membrane receptor tyrosine kinase, are now available for use as an immunohistochemical label for ICCs in some species. ${ }^{14}$ Many regions of the GI tract display spontaneous electrical rhythmicity. ${ }^{15}$ Auto-rhythmicity in GI muscles is an exclusive property of ICCs and the spread of slow waves through GI muscles occurs electronically, not by active regeneration. Slow waves, pacemaking by ICCs, are organized into electrically coupled networks within discrete areas of the stomach, small bowel and colon.

Interestingly, some reports have recently suggested the loss of ICC networks in diabetic patients and animal models. ${ }^{16,17}$ These showed the involvement of ICCs on DM-related GI motor abnormalities. Kim et $\mathrm{al}^{18}$ examined the nature of colonic dysfunction in a long-term diabetic rat model. They found that the spontaneous contractility of proximal colon and the ICC networks were decreased in the diabetes rats. This result supports

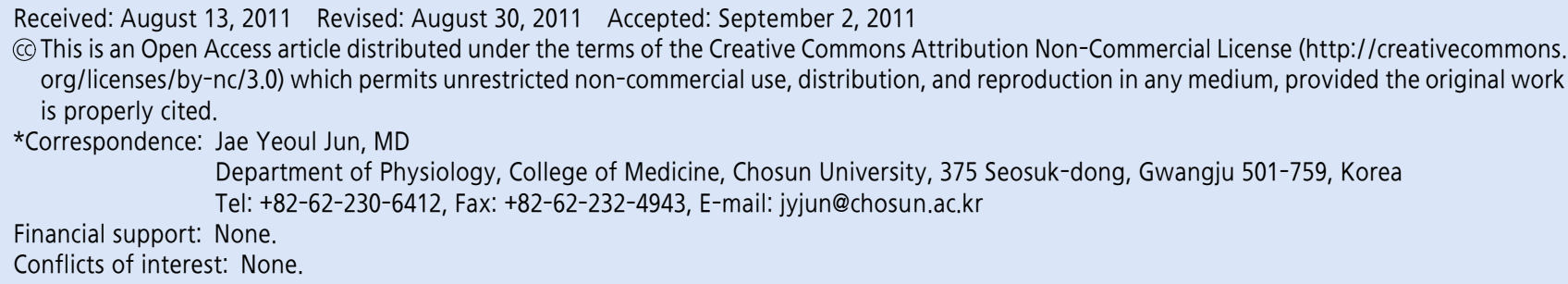


the previous findings that the involvement of ICCs has showed in diabetic patients and animal models. ${ }^{16,17}$

Kim et $\mathrm{al}^{18}$ indicated that the response of carbachol or nitric oxide in proximal colon of the diabetic rats was significantly decreased. It is well known that acetylcholine plays important roles for modulation of GI motility and the existence of receptors for acetylcholine in ICCs and smooth muscle of the GI tract was mentioned in many reports. ${ }^{19-21}$ Nitric oxide (NO) is also a major nonadrenergic, noncholinergic inhibitory neurotransmitter in GI tract and the release of $\mathrm{NO}$ causes relaxation of the smooth muscle. ${ }^{22,23}$ It has been reported that NO has an effect on the electrical activity of ICCs as well. ${ }^{24}$ However, Kim et al ${ }^{18}$ did not show the exact mechanism what kind of cells is involved in the diabetic rats. Nevertheless, they proposes strong evidence regarding the role of ICCs on GI motor abnormalities in diabetic rats. The number of acetylcholine receptor and the production of nitric oxide can affect the DM-related motor symptoms.

\section{References}

1. Folwaczny C, Riepl R, Tschöp M, Landgraf R. Gastrointestinal involvement in patients with diabetes mellitus: Part I (first of two parts). Epidemiology, pathophysiology, clinical findings. Z Gastroenterol 1999;37:803-815.

2. Verne GN, Shinsky CA. Diabetes and the gastrointestinal tract. Gastroenterol Clin North Am 1998;27:861-874, vi-vii.

3. Bytzer P, Talley NJ, Leemon M, Young LJ, Jones MP, Horowitz M. Prevalence of gastrointestinal symptoms associated with diabetes mellitus: a population-based survey of 15,000 adults. Arch Intern Med 2001;161:1989-1996.

4. Feldman M, Schiller LR. Disorders of gastrointestinal motility associated with diabetes mellitus. Ann Intern Med 1983;98:378-384.

5. Ko GT, Chan WB, Chan JC, Tsang LW, Cockram CS. Gastrointestinal symtoms in Chinese patients with type 2 diabetes mellitus. Diabet Med 1999;16:670-674.

6. Rothstein RD. Gastrointestinal motility disorders in diabetes mellitus. Am J Gastroenterol 1990;85:782-785.

7. Horowitz M, Samsom M. Gastrointestinal function in diabetes mellitus. Chichester: John Wiley \& Sons, Ltd 2004:1-337.

8. Mayhew TM, Carson FL, Sharma AK. Small intestinal morphology in experiment diabetic rats: a stereological study on the effects of an aldose reductase inhibitor (ponalrestat) given with or without conventional insulin therapy. Diabetologia 1989;32:649-654.

9. Tahara T, Yamamoto T. Morphological changes of the villous microvascular architecture and intestinal growth in rats with streptozotocin-induced disbetes. Virchows Arch A Pathol Anat Histopathol
1988;413:151-158.

10. Langton P, Ward SM, Carl A, Norell MA, Sanders KM. Spontaneous electrical activity of interstitial cells of Cajal isolated from canine proximal colon. Proc Natl Acad Sci USA 1989;86:7280-7284.

11. Sanders KM. A case for interstitial cells of Cajal as pacemakers and mediators of neurotransmission in the gastrointestinal tract. Gastroenterology 1996;111:492-515.

12. Sanders KM, Koh SD, Ward SM. Interstitial cells of Cajal as pacemakers in the gastrointestinal tract. Annu Rev Physiol 2006;68:307343.

13. Park KJ. Interstitial cells of Cajal and GI motility. Korean J Neurogastroenterol Motil 2004;10:93-99.

14. Ward SM, Burns AJ, Torihashi S, Sanders KM. Mutation of the proto-oncogene c-kit blocks development of interstitial cells and electrical rhythmicity in murine intestine. J Physiol 1994;480(Pt 1):9197.

15. Szurszewski JH. Electrical basis for gastrointestinal motility. In: Johnson LR, ed. Physiology of the gastrointestinal tract, 2nd ed. New York: Raven Press 1987:383-422.

16. Iwasaki H, Kajimura M, Osawa S, et al. A deficiency of gastric interstitial cells of Cajal accompanied by decreased expression of neuronal nitric oxide synthase and substance $\mathrm{P}$ in patients with type 2 diabetes mellitus. J Gastroenterol 2006;41:1076-1087.

17. Forrest A, Huizinga JD, Wang XY, Liu LW, Parsons M. Increase in stretch-induced rhythmic motor activity in the diabetic rat colon is associated with loss of ICC of the submuscular plexus. Am J Physiol Gastrointest Liver Physiol 2008;294:G315-G326.

18. Kim SJ, Park JH, Song DK, et al. Alterations of colonic contractility in long-term diabetic rat model. J Neurogastroenterol Motil 2011; 17:372-380.

19. Huizinga JD, Chang G, Diamant NE, El-Sharkawy TY. Electrohysiological basis of excitation of canine colonic circular muscle by cholinergic agents and substance P. J Pharmacol Exp Ther 1984;231: 692-699.

20. Inoue R, Chen S. Physiology of muscarinic receptor-operated nonselective cation channels in guinea-pig ileal smooth muscle. EXS 1993;66:261-268.

21. Kim TW, Koh SD, Ordög T, Ward SM, Sanders KM. Muscarinic regulation of pacemaker frequency in murine gastric interstitial cells of Cajal. J Physiol 2003;546(Pt 2):415-425.

22. Sanders KM, Ward SM. Nitric oxide as a mediator of nonadrenergic noncholinergic neurotransmission. Am J Physiol 1992;262(3 Pt 1): G379-G392.

23. Ueno T, Duenes JA, Zarroug AE, Sarr MG. Nitrergic mechanisms mediating inhibitory control of longitudinal smooth muscle contraction in mouse small intestine. J Gastrointest Surg 2004;8:831841.

24. Park CG, Kim YD, Kim MY, et al. Inhibition of pacemaker currents by nitric oxide via activation of ATP-sensitive $\mathrm{K}^{+}$channels in cultured interstitial cells of Cajal from the mouse small intestine. Naunyn Schmiedebergs Arch Pharmacol 2007;376:175-184. 